\title{
Mellemøst-konflikten fra 1948 til 2005
}

\section{Christian Oldenburg}

Fremragende indføring i den mellemøstlige konflikt med et væld af detaljer og uden at de lange linjer på nogen måde tabes af syne

Lars Blinkenberg: The Middle East Conflict - From Bad to Worse to War, Syddansk Universitetsforlag, 2006 og Lars Blinkenberg: The Middle East Conflict - From Bad to Worse to War - Brief History of Involved Countries, Multivers, 2006

Lars Blinkenberg har efter sin pensionering skrevet en grundlæggende indføring i den mellemøstlige konflikt mellem Israel og alle dets naboer fra 1948 (med visse forklaringer om og beskrivelser af tiden længere tilbage) og frem til 2005. Ikke mindst Lars Blinkenbergs sidste stilling i udenrigstjenesten som Danmarks ambassadør i Damaskus, Amman, Beirut og Nicosia har givet ham megen viden om Mellemøsten og kendskab til centrale aktører, som hans værk nyder godt af.

Lars Blinkenberg har valgt den lidt usædvanlige form at gennemgå selve den israelsk-arabiske konflikt i værkets første bind, mens han i andet bind fylder hullerne i konfliktens historie ud ved land for land at gennemgå Israels, Egyptens, Jordans, Syriens, Libanons og Palæstinas historie og indenrigspolitik i den samme periode.

Metoden medfører på den ene side visse overlapninger eller gentagelser, men på den anden side sikrer den, at oplysninger om udviklingen i de enkelte lande, som er nyttige og nødvendige for den samlede forståelse, ikke bliver forbigået, fordi de er svære at passe ind i konfliktens hovedhistorie.

For mig at se er det lykkedes for Lars Blinkenberg gennem sin metode at få det væsentlige med på de kun godt 550 sider i alt i de to bind. Man kan undre sig over, at Syddansk Universitetsforlag ikke så det på samme måde, hvorfor værket har 


\section{LITTERATUR Mellemøst-konflikten fra 1948 til 2005}

måttet udgives på to forskellige forlag - dog med et helt identisk udseende.

Værkets styrke er den kølige beskrivelse af, hvad der faktisk skete internationalt og nationalt - selv om naturen af og til går over optugtelsen gennem nogle overflødige adjektiver, der forstyrrer det ret 'kliniske' værk. Men der svælges ikke i krigenes, voldens og undertrykkelsernes drama og gru, der fokuseres ikke på alle parternes (inkl. stormagternes) dumheder og fejl.

Bogen kunne have været fyldt med langt flere giftige bemærkninger om 'denne verdens dårskab'. Læseren må også læse mellem linjerne.

\section{Tankevækkende nyt}

For mig, der har fulgt Mellemøstens udvikling tæt i mange år, er det Lars Blinkenbergs gennemgang af begivenhederne i konfliktens første år frem til 1967, der er det mest nye og mest spændende i bøgerne.

Lars Blinkenberg har i høj grad udnyttet den nyeste, såkaldt revisionistiske, israelske historieforskning, som bl.a. Benny Morris og Avi Shlaim har gennemført på grundlag af adgang til Israels arkiver. Dermed ikke være antydet, at Lars Blinkenbergs gennemgang af begivenhederne i Mellemøsten fra 1967 og til 2005 ikke også er yderst interessant. Der var blot ikke meget nyt for mig personligt i de dele af værket.
Det var således tankevækkende for mig at læse i Lars Blinkenbergs værk, at Israel fra første øjeblik var afvisende over for fredsfølere fra de arabiske naboer, hvorfor Israels udenrigsminister i perioden 1948 56 , Moshe Sharett, der ønskede seriøst at udforske åbningerne i Egyptens, Jordans og Syriens holdninger, måtte se alle sine bestræbelser stran$\mathrm{de}$, når sagerne nåede til premierminister (1948 - 53 og 1955 - 63) David Ben-Gurions bord.

Det er ganske som i dag, hvor alle de arabiske landes gentagne tilbud til Israel om 'fuld fred for fuld tilbagetrækning' (til linjen den 4. juni 1967) knapt nok værdiges et svar fra Israels side.

Det var også nyt for mig, at Israel lige fra begyndelsen anlagde en linje, der indebar helt uproportionelle reaktioner på arabiske provokationer. Det Gamle Testamentes ord om 'et øje for et øje og en tand for en tand' synes helt at være glemt og erstattet med 100 øjne for et øje og 100 tænder for en tand.

Og ikke blot reagerede Israel ekstremt voldsomt lige fra starten på små gruppers grænsekrænkelser og voldelige aktioner, Israel foretog også helt uprovokerede aktioner i de arabiske lande. Eksempler på tidlige og uproportionelt voldsomme reaktioner er Qibya (1953) og invasionen af Egypten (1956).

Et eksempel på en tidlig, helt uprovokeret aktion er de israelske agenters bombeangreb i sommeren 
1954 på civile, overvejende 'vestlige' mål i Kairo for at svække den egyptiske regering og skabe spændinger mellem Egypten og de vestlige magter. Disse aktioner, 'Lavon affæren' efter Israels daværende forsvarsminister Pinchas Lavon, blev oven i købet gennemført uden at den daværende israelske premierminister (1953 - 55), Moshe Sharett, var underrettet på forhånd.

Lavon må have anset det for så rutinemæssigt at sende bombemænd til et naboland, at premierministeren ikke skulle besværes med sådanne detaljer. Sharett blev først bekendt med disse israelske bombeangreb i Kairo, da flere israelske agenter kom for retten i Egypten sigtet for terrorisme.

Det kan i høj grad undre, at Israel i så mange år og i hele sin historie har fastholdt en linje med at overse arabiske fredsfølere og at gennemføre såvel helt uproportionelle reaktioner som helt uprovokerede aktioner mod araberne, når det er helt åbenlyst, at denne politik ikke virker - eller i hvert fald ikke opnår de erklærede mål. Virkede politikken, er det i den virkelige verden selvsagt en anden sag. Men man kan ikke banke folk til at elske sig. Efter 58 år er Israel længere end nogensinde fra rigtig fred og sikkerhed.

\section{Besøget på Tempelbjerget}

Lars Blinkenberg har den seneste store, uprovokerede aktion med i sin bog. Det var den 28. september 2000, da lederen af den daværende israelske opposition, Ariel Sharon ledsaget af mange hundrede, svært bevæbnede livvagter (ifølge Lars Blinkenberg, andre sætter tallet højere) - uinviteret besøgte islams tredjevigtigste helligdom, området på Haram al Sharif (israelerne kalder stedet Tempelbjerget eller Mount Zion) med Omar og al Aqsa moskeerne.

Det meget store antal svært bevæbnede folk på et helligt sted i ØstJerusalem sættes i relief af, at da jeg var ambassadør i Bagdad i 2005 - 06, havde selv udenlandske ministre og ambassadører under de farligste situationer i Irak normalt højst 5 - 20 livvagter.

Sharons besøg var den handling, som midt i de afgørende israelsk-palæstinensiske forhandlinger efter Camp David i sommeren 2000 og før Taba i januar 2001, udløste den anden intifada, som har ført parterne længere og længere fra hinanden. At palæstinenserne også overreagerer og skader deres egen sag, viser dette eksempel også.

Det seneste eksempel på en helt uproportionel israelsk reaktion på arabiske provokationer har Lars Blinkenberg af gode grunde ikke med. For da var værket udkommet. Det er begivenhederne i sommeren 2006 i Gaza og i Libanon.

Når jeg nævner det, er det for at underbygge Lars Blinkenbergs dokumentation af de lange linjer i 


\section{LITTERATUR Mellemøst-konflikten fra 1948 til 2005}

Mellemøsten. I skrivende stund er de tre israelske soldater, der lod sig tage til fange af guerillagrupper, ikke blevet befriet/løsladt, men store dele af Gaza og Libanon er som så mange gange tidligere blevet ødelagt, mange er blevet dræbt, såret eller flygtet på grund af luft- og artilleriangrebene, og hverken Hizbollah eller de palæstinensiske guerillaer er blevet slået. De kunne fortsætte deres aktioner mod Israel helt frem til våbenstilstanden trådte $\mathrm{i}$ kraft.

De voldsomme og mislykkede israelske aktioner i 2006, som ligger i klar forlængelse af tidligere israelske aktioner, der bliver næunt af Lars Blinkenberg, er så meget desto mærkeligere af to grunde. For det første er moderne, højteknologisk krigsførelse ikke særlig effektiv over for motiverede guerillastyrker, og hvornår lærer man det? For det andet er der fredelige løsninger, der ligger lige for. Den enkle løsning er, som man har gjort det før i den mellemøstlige konflikt, at gennemføre en fangeudveksling, og der er i de israelske fængsler rigeligt med libanesere og palæstinensere, der ikke er dømt for noget.

Hertil kommer, at Israel kunne løse problemerne med Hizbollah ved slutte fred med Syrien på det kendte grundlag (forhandlingerne i Wye River 1995 - 96 og i Simonstown 1999 - 2000). Grunden er, at når Syrien har fået hele Golan tilbage, har det sekulariserede syriske regime ingen interesse i at hjælpe og ingen brug for det religiøst ekstreme ('fundamentalistiske') Hizbollah tværtimod.

Men disse muligheder har Israel og dets støtter ikke været interesseret i.

\section{Det meste er med}

Samtidigt har Lars Blinkenbergs værk den store styrke, at det meste er med.

Hvis der er nogen, der ikke ved, hvad der skete i Deir Yassin lige vest for Jerusalem den 9. april 1948, hvor Israels senere premierminister, Menachem Begin, havde en ledende rolle; hvis der er nogen, der har glemt, at Israels senere premierminister Yitzhak Shamir var central blandt de ansvarlige for mordet på Folke Bernadotte den 17. september 1948 i Jerusalem (det havde Olof Palme ikke glemt, da han var svensk statsminister i 1980'erne samtidigt med, at Yitzhak Shamir var premierminister i Israel, hvorfor der ikke var svensk-israelske ministerbesøg på den tid - for hvem i den svenske regering ville trykke Folke Bernadottes morder i hånden); hvis der er nogen, der ikke har hørt om begivenhederne i Qibya i Jordan i oktober 1953, hvor Israels senere premierminister Ariel Sharon ledede den israelske aktion; hvis slaget ved alKarameh i Jordan i marts 1968, hvor de 15.000 israelske pansertropper af jordanske og/eller palæstinensiske tropper blev tvunget til at trække sig 
tilbage til vest for Jordan floden, skulle være glemt af nogen (bl.a. dem, der fx i 1978, i 1982, i 1996 og i 2006 mente, at militære invasioner og bombardementer af Libanon var en strålende og især meget effektiv idé); hvis nogen ikke kan huske begivenhederne i Sabra og Chatila i Beirut i september 1982, som Israels daværende forsvarsminister, Ariel Sharon, var ansvarlig for, fordi den maronittiske milits, der gjorde det beskidte arbejde, fik lov af israelerne til at operere $\mathrm{i}$ lang tid dybt inde $\mathrm{i}$ det israelsk besatte, muslimske VestBeirut, og fordi Sabra og Chatila ligger nede i dalen lige uden for det daværende israelske hovedkvarter på en bakketop i Vest-Beirut; hvis de ikke ved det, skal de læse Lars Blinkenbergs værk.

For hvis man ikke kender disse begivenheder, som alle arabere har en klar viden om, skal man slet ikke begynde at tale med om den israelskarabiske konflikt, i hvert fald ikke hvis man vil fremstå som mægler.

\section{Religionernes betydning}

Men alt er selvfølgeligt ikke med i Lars Blinkenbergs værk, når man kun har godt 550 sider til sin rådighed.

Skulle man pege på et emne, som er stedmoderligt behandlet af Lars Blinkenberg, er det religionernes betydning for den mellemøstlige konflikt. Ikke blot har den israelske part i konflikten et klart religiøst aspekt i sig (at opfylde Guds angivelige løfte til Abraham og hans efterkommere, der var jøder (alt land mellem Nilen og Eufrat, jf. 1.Mos. 15,18)), som - også i kraft af de stærke religiøse partier i Knesset sætter grænser for Israels regerings bevægelsesfrihed.

For mig at se er også de militante, ekstreme muslimers voksende indflydelse i de arabiske lande siden 1970'erne en meget væsentlig faktor, der begrænser og vanskeliggør de mere (meget) sekulariserede arabiske lederes manøvremuligheder i den mellemøstlige konflikt. I årtier har de militante, ekstreme muslimers voldelige angreb på sekulariserede (frafaldne) arabere og vantro udlændinge m.v. været en stadig trussel mod regeringerne i Kairo, Damaskus og Amman.

I denne sammenhæng kan det også nævnes, at den eneste stærke milits, der er tilbage i Libanon, og som ingen magt i landet kan styre, er den militante shiamuslimske milits Hizbollah, som i 18 år (1982 2000) med succes bekæmpede den israelske besættelsesmagt i Syd-Libanon, og som i sommeren 2006 effektivt modstod de massive israelske angreb på bl.a. Hizbollahs baser og stillinger.

De militante, ekstreme muslimske gruppers voksende politiske styrke er selvsagt også en faktor, der hæmmer demokratiudviklingen i den arabiske verden. Man kan blot se på Irak, som var det mest moderne og 


\section{LITTERATUR Mellemøst-konflikten fra 1948 til 2005}

sekulariserede arabiske land for 30 år siden, og som nu gennem demokratiske valg i alt væsentligt er blevet overtaget af magtsøgende, indbyrdes stridende, religiøse politikere, der hver har deres egen milits.

Det bør også ved lejlighed udforskes, i hvor høj grad Israel hjalp Hamas frem som et religiøst alternativ til det sekulariserede PLO (at Israel gjorde det, er der ingen tvivl om, men spørgsmålet er, hvor meget Israel gjorde for Hamas i de første år), og om Israel nu er tilfreds med, at det stort set er lykkedes at sætte PLO/Fatah skakmat, eller om Israel fortryder, at det såede vind for at høste storm. Ganske som USA formentlig ikke i dag er stolt af al den hjælp og uddannelse, som Osama bin Laden og al-Qaeda fik af USA i Afghanistan i 1980'erne.

Men når det er sagt, er Lars Blinkenbergs værk om konflikten i Mel- lemøsten en fremragende indføring i den mellemøstlige konflikt. Dens væld af detaljer, uden at de lange linjer på nogen måde tabes af syne, gør, at den klart og varmt kan anbefales til alle, der skal sætte sig ind i forholdene i Mellemøsten.

Det være sig forretningsfolk, journalister, medarbejdere i NGO'er, embedsfolk, politikere etc., der ikke har en lang erfaring med enkelthederne i Mellemøstens sørgelige, nyere historie. Men også for folk, der kender den, er der nye oplysninger og betragtninger i Lars Blinkenbergs værk, som medfører, at alle har udbytte af at læse den.

Christian Oldenburg er ambassadør og Danmarks faste representant ved Europarådet i Strassbourg. Han har tidligere varet ambassadør i bl.a. Damaskus, Cairo og Bagdad 